\title{
ARTICLE
}

\section{Two Conceptions of An Environmental Ethic And Their Implications}

\section{A. Introduction}

It is becoming all too clear that, unless radical steps are taken, we are in danger of maiming our environment and many of its nonhuman inhabitants beyond recognition. The problems resulting from pollution, depletion of the earth's resources, and economic development at the expense of land, air, and water grow increasingly severe. Animals are being deprived of their habitats, and species are becoming endangered or extinct at an alarming rate. It is imperative that we change our environmental policies. Effective policy changes require a coherent ethical basis, however, and environmentalists thus far have not been noted for their philosophical unity. Many different positions have been taken, from the allegedly "moderate" attitude of a William Ruckelshaus, to the advocacy of ecological sabotage by. "Earth First," a group inspired by a novel (Edward Abbey's The Monkey Wrench Gang) in which machines are trashed, bridges blown up, and human life treated cavalierly at best. ${ }^{2}$ Ecologist Garrett Hardin quite seriously proposes that wilderness areas contain no emergency roads and that backpackers who get stranded find their own way out or die (to bring in helicopters would defile the serene beauty of the surroundings). ${ }^{2}$ The diversity of environmentalist views, many of them with unpalatable consequences to most humans, has made environmentalism an easy target for its detractors.

A coherent environmental ethic is necessary for the resolution of this situation. But how can such an ethic be formulated and what would its implications be for human and nonhuman animals? Are those implications morally defensible? I will not attempt to give a comprehensive treatment of all the issues that have been raised by the growing literature on environmental ethics. Rather, I will consider the two major rival conceptions of an environmental ethic which are emerging from the literature: individualism and holism. I will sketch what I take the implications of each for humans and nonhumans to be, then discuss important objections to each view. I will argue that the individualistic conception has more to recommend it from the moral point of view. However, the holistic approach has merit also, and I will try to show that an adequate environmental ethic should contain elements from both conceptions.

\section{B. Preliminary Distinctions}

I will begin with some necessary distinctions. By 'ethic' I mean a comprehensive, coherent set of principles of value and obligation. Of the two types of principles, those concerning value are more fundamental. The moral rightness of an act depends, wholly or in part, on whether it promotes that which is intrinsically valuable; i.e., valuable for its own sake. Beings are intrinsically valuable to the extent to which they possess certain properties. Just which properties those are must be determined by an ethic's theory of value. Some candidates are: having the capacity to experience pleasure or happiness; having the capacity for knowledge; having the capacity for freedom; beauty, harmony, health, and life. Such properties, and the 
events or states of affairs which exemplify them, are morally relevant according to an ethic, but only beings can be said to have moral standing or to be morally considerable. Because of the properties certain beings have, we are obligated to consider how they would be affected by a given action or policy. Morally considerable beings are valuable in their own right. It follows that it would be wrong to treat them as instrumentally valuable only; i.e., as mere instruments for the production of other value. ${ }^{3}$ An ethic must determine which beings are to count as morally considerable, and it must do so on the basis of morally relevant characteristics. It must also arrive at a nonarbitrary criterion of moral significance which will allow for the resolution of conflicts among morally considerable beings.

An ethic is environmental if and only if it accords moral standing to some nonsentient beings. ${ }^{4}$ Some plants, natural objects, or systems must count as being valuable in their own right. An ethic which classifies all such beings as merely instrumentally valuable would be, in Tom Regan's words, an ethic "for the use of the environment," 5 not an environmental ethic. An environmental ethic is not a narrowly focused set of principles pertaining only to what we call "environmental issues." It will have implications for all beings with moral standing, whoever or whatever they may be.

What beings have moral standing? According to the individualistic conception of an environmental ethic, only individual entities (hereafter, simply 'individuals') can be morally considerable, be they humans, nonhuman animals, or redwoods. On such a view, ecosystems and species have no moral standing. According to the holistic conception of an environmental ethic, it is complex systems of individuals ('beings' in a broad sense of the term) which have moral standing: individuals as such have none. I will refer to these views as environmental individualism and environmental holism, respectively.

How is one to evaluate these two conceptions of an environmental ethic? How can one determine whether either is more justifiable than a more traditonal ethic for the use of the environment? It would be impossible to discuss the vast literature on the meaning and justification of ethical views here, so I will simply offer a proposal which most contemporary ethical theorists accept. Whatever it may mean to say that a human, fox, lake or species is intrinsically valuable, it is plain that one's judgment must meet some minimal criteria. If one's judgment is (1) not informed about the relevant facts, including the information one gains about sentient beings through empathy, or (2) is not clearly thought out, or (3) is not impartial, or (4) is not universalizable, then that judgment is not justified. Conversely; if a judgment of intrinsic value meets all these conditions, it is as justified as an ethical judgment can ever be: it is well-considered. Therefore, the ethics in question will be tested by taking the moral point of view: we will try to determine whether they stand up to clear, informed, impartial scrutiny when universalized. We can call this an appeal to those famous "ethical intuitions," provided we never forget that those intuitions must be well-considered. An appeal to such intuitions is not to be confused with an appeal to simplistic moral biases. Those philosophers who attack the method of appealing to intuitions are really just objecting to the latter practice. ${ }^{6}$

\section{The Failure of the Homocentric Ethic}

Before turning to environmental individualism and holism, let us 
briefly consider their traditional rival: the homocentric ethic. According to it, all and only human beings have moral standing. Nonhuman animals, plants, or natural objects have value only in so far as they serve human interests. The chief theoretical defect of the homocentric ethic is the arbitrary nature of its criterion of moral considerability. To exclude from the realm of moral considerability those nonhuman animals who differ from (some) humans in no respect other than species-membership is to be guilty of a kind of thinking akin to racism, as Peter Singer has argued. ${ }^{7}$

Apart from this devastating defect, moreover, the homocentric ethic fails to accord with our considered views about environmental preservation. It is, of course, true that enlightened, long-range homo-sapiens-interest would justify many environmentally sound policies: e.g., the halting of further depletion of the ozone layer by fluorocarbons, the reduction of other air, land, and water pollution that harms humans, and the safer disposition of toxic wastes. Surely we could improve upon some of our current "caretakers" who, believing that the Second Coming is at hand, think there will be no future generations to benefit from a clean environment. Nevertheless, the homocentric ethic cannot go far enough. Its fatal flaw, as Eric Katz has argued, is its making environmental preservation contingent on human attitudes:

\section{Basing arguments for environ- mental preservation on the premises of utilitarian moral theory will only reveal the precarious relationship which exists between the satisfaction of human needs and the pres- ervation of natural objects. ${ }^{8}$}

There are many species of animals and plants which few humans value, whose extinction would not harm us: e.g., snail-darters, dusky-footed woodrats, the furbish lousewort (an unassuming and rare little plant), and perhaps even the timber wolf. ${ }^{9}$ As the case of the Tellico Dam shows, elimination of some species may result from policies which benefit humans economically and recreationally: (Fortunately for the snail-darters, they have another habitat which is as yet uncoveted by humans.) Human interests might be better satisfied if we reduced the number of animal species, putting their former habitats to economically better use. Why not follow the general policy which we see pursued in Borneo, where orangutans are losing their forest homes to farms? We could save cute, cuddly, and bizarre representatives of some of these species for display in zoos, where they are so much easier to see and enjoy. Turning to some nonsentient parts of our environment, we have already seen the shrinkage of the amount of parks and wilderness areas in the public domain. Those that remain are often polluted (from an environmentalist point of view) by superhighways, motels, restaurants, laundromats, motorcycles, motorboats, snowmobiles and land-rovers. Far too many areas have been "Yosemitized." Yet, these measures may well have resulted in a greater amount of human satisfaction. For every furious Sierra Club member, there are many contented tourists.

Moreover, it might be very beneficial from a homocentric point of view to alter some environmental attitudes which many people still have. Martin Krieger, in an article in Science called "What's Wrong with Plastic Trees?," argues that

the demand for rare environments is a learned one. It also seems likely that conscious public choice can manipulate this learning so that the environments which people learn to 
use and want reflect environments that are likely to be available at low cost... What's wrong with plastic trees? My guess is that there is very little wrong with them. Much more can be done with plastic trees and the like to give most people the feeling that they are experiencing nature. ${ }^{10}$

Would it even be all that difficult to change people's attitudes in this direction? Plastic flowers and artificial house plants are already favored by many, as are fake-animal lawn ornaments. Why not put astroturf under the ceramic deer, chicks, bunnies, and flamingoes? Many people already find the charms of mechanical beasts in the wilds of Disneyland much more appealing than those of their less entertaining natural counterparts. We would not need to make the special, costly efforts which preservation of rare environments and wild animals call for if most people became satisfied with cheap replacements.

It is evident that the homocentric ethic makes the environment, as well as individual animals, hostage to the interests which humans happen to have. These interests frequently run counter to environmental preservation. I maintain that reflection about our "Yosemitized" parks and the prospect of environmental plastification shows this implication to be unacceptable. Since it does not accord with our considered view, the homocentric ethic fails to be an adequate ethic for the use of the environment.

\section{Environmental Individualism}

Let us see whether environmental individualism is an improvement on the homocentric ethic. Some recent proponents of this view have been Christopher Stone, ${ }^{11}$ Tom Regan, ${ }^{12}$ and Donald Scherer. ${ }^{13}$ Environmental individualism accords moral standing to humans, sentient nonhuman animals, and some plants and natural objects. This ethic has two chief advantages over a homocentric ethic. First, it does not accord moral standing on the basis of a morally irrelevant characteristic: species. It is in agreement with the considered view that sentient nonhuman animals have value in their own right, that they are not to be regarded as mere instruments for human gratification. Second, such a view implies that extensive exploitation, pollution, and plastification of the environment is wrong, even if it could be done without harming the chances for human survival and enjoyment. This too, I maintain, agrees with our considered views. Environmental individualism makes neither nonhuman animals nor wilderness areas hostage to the preferences people happen to have. Thus, it is superior from the moral point of view to the homocentric ethic. However, several serious objections have been pressed against environmental individualism. Let us consider each in turn.

1. Holists have charged that environmental individualism is objectionably atomistic. E.g., Alistair Gunn argues that

[Holistic] environmentalism seems incompatible with the 'Western' obsession with individualism, which leads us to resolve questions about our treatment of animals by appealing to the essentially atomistic, competitive notion. of rights... 14

The same objection is made more fully by Kenneth Goodpaster, in a frequently cited article critical of individualism in ethics:

I am convinced that the mere enlargement of the class of morally considerable beings is an inadequate substitute for a 
genuine environmental ethic. . - the oft-repeated plea by some ecologists and environmentalists that our thinking needs to be less atomistic and more 'holistic' translates into a plea for a more embracing object of moral consideration. In a sense, it represents a plea to return to the richer Greek conception of a man by nature social and not intelligibly removable from his social and political context-though it goes beyond the Greek conception in emphasizing that societies too need to be understood in a context, an ecological context, and that it is this larger whole that is "the bearer of value."15

The objection is that any ethic which restricts moral standing to individuals, be they sentient or nonsentient, ignores the mutual dependencies of individuals and the larger ecological context which includes them. It is these large systems which are intrinsically valuable, not the individuals they include.

I believe this objection to be doubly mistaken. First, it attacks a "straw ethic." No one who advocates an individualistic ethic, whether or not it includes nonsentient beings, is unaware of the mutual dependencies of individuals and their reliance on land, air, and water for existence. Of course individuals do not exist in isolation. To paraphrase John Donne, no lousewort is an island unto itself. Second, it simply does not follow that if an individual is a member of a large complex whole, without which it could not exist, the whole rather than the individual must be "the bearer" of intrinsic value. Would we say that a child who is a member of a richly complex family unit thereby lacks all value in his own right, the family (not its members!) alone having intrinsic value? The inference is a non sequitur. Thus environmental individualism survives this objection.

2. An objection has been raised against proponents of "animal liberation" which also applies to environmental individualists. Views according to which sentient beings, regardless of their origins and special characteristics, are morally considerable are said to conflict with our considered intuitions that wild animals are of vastly greater value than domestic animals. J. Baird Callicott writes that there is "a sharp distinction between the very different plights (and rights) of wild and domestic animals."16 He suggests that domestic animals have little or no moral standing:

Domestic animals are creations of man: They are living artifacts, but artifacts nevertheless, and they constitute yet another mode of extension of the works of man into the ecosystem. From the perspective of the land ethic a herd of cattle, sheep or pigs is as much or more a ruinous blight on the landscape as a fleet of four-wheel-drive off the road vehicles. ${ }^{17}$

Domestic animals are said to be objectionable human artifacts, having been "bred to docility, tractability, stupidity and dependency."18 Wild animals, on the other hand, have much more admirable qualities, qualities without which they could not have survived. It is the latter, Callicott suggests, not the former, which our intuitions tell us are fit objects of our concern. They belong in the world in which they have naturally evolved; the pathetically unfit creatures of our own making do not.

The inhumane treatment of penned domestics should not 
be, I suggest, even discussed in the same context as whaling and wildlife traffic; it is a disservice to do so. ${ }^{19}$

In reply to this objection, it should first be noted that environmental individualism need not imply that domestic and wild animals have equal intrinsic value. To say that they are all morally considerable is not yet to say that they should be given the same degree of moral consideration. To think otherwise is to confuse the criterion of moral considerability with the criterion of moral significance. ${ }^{20} \mathrm{Sec}-$ ond, it does indeed seem plausible that domestic and wild animals ought to be accorded different treatment, but the difference ought to be in favor of the domestic animals. Doesn't the manner in which we deliberately created these creatures increase rather than decrease our obligation to them? Consider the following parallel. We believe that we have special responsibilities to those humans whom we bring into existence in accordance with our culturally inculcated preferences for certain numbers and sex distributions of progeny, at least until they are mature. But whbt if we arranged it so that they did not reach maturity? Suppose, a la Aldous Huxley, we used genetic engineering techniques to create human beings who were deliberately stunted into docile bovine idiocy. We might save some particularly attractive ones for pets, but most will be put to work. We train them to do the jobs not fit for intelligent sensitive humans, we use them for experiments which will benefit us, often causing them agony, and we eat the tasty ones after subjecting them to factory-farming techniques that cause them great misery. (Dimwitted though they are, they still have the capacity to suffer, as do domestic animals.) It seems to me that we would owe these creatures a great deal, including moral consideration. From the moral point of view, the plight of our stunted domestic humans is on all fours with the plight of our domestic animals. I can only conclude that we have greater, not lesser, moral obligations to these dependent "artifacts" than to their independent wild aboriginal progenitors. This conclusion squares well with the environmentalist view that wild animals ought not to be interfered with unless interference is required to restore a balance we earlier disturbed. Thus, it seems that environmental individualism does not conflict with our considered views about domestic and wild animals after all.

3. It has been objected that the extension of an ethic to include nonhuman or nonsentient individuals stretches our moral concepts out of all recognition. Goodpaster puts this objection well:

The "individualistic" model strains our moral sensitivities and intuitions to the breaking point, inviting talk of the "rights of animals," from dolphins to mosquitoes; "rights," and even duties, of natural objects like trees and rivers; "chauvinism"; and court suits brought in the names of personified species or even historical landmarks. ${ }^{21}$

I must confess that 1 do not find talk of animal rights to be counter-intuitive, provided the animals are sentient, but the extension of such talk to nonsentient beings is another matter. One does indeed quail at the thought of carrying banners for rocks' rights and lousewort liberation. Does the Mississippi river have the right not to have its course altered by Louisiana civil engineers? Do redwoods have duties to squirrels? A view which has such implications is very suspect. Some versions of environmental individualism are open 
to this objection. E.g., law professor Christopher Stone argues that "it is not unthinkable" to accord rights to natural objects like rivers, trees, and rocks, and he believes humans ought to represent those rights in courts of law. ${ }^{22}$ Why not "unthinkable?" Revealingly, Stone ties his view to a Whiteheadian idealism which accords consciousness to all natural objects, including plants and rocks and even atoms. He even recommends that we regard the entire planet as a conscious entity. ${ }^{23}$

It is not clear whether Stone believes this to be true or is simply proposing it as a useful "myth." 24 If it is just a myth, and we have every reason to believe that it is, it can hardly justify any rights ascriptions to nonsentient objects. To accord rights to rocks, at least, is to do violence to the concept of rights, a concept which, as Joel Feinberg has argued, entails that every rightsholder has interests. ${ }^{25}$ It makes sense to say that sentient beings have interests, but what about nonsentient beings? In a very stretched sense of 'interest," we can attribute interests to, e.g., grass (it needs sun and water). But then we can also say that lawnmowers have an interest in having their engines oiled and their blades sharpened. As Bryan Norton argues, if we base rights-ascriptions on such a watered-down concept of interests, they become entirely arbitrary. ${ }^{26}$ Thus objection (3) has considerable force against views which ascribe rights to nonsentient beings.

However, environmental individualism need have no such implication. The concepts of 'having a right' and 'being morally considerable' are not coextensive, as Goodpaster himself points out. ${ }^{27}$ We may accord all sentient beings rights (though not necessarily the same rights) without according rights to nonsentient beings, while nevertheless regarding some of the latter as being morally considerable. But at this point, the objection re-emerges: does not such a suggestion stretch our concept of moral considerability out of all recognition? ${ }^{28}$ An excellent case can be made for the moral considerability of sentient individuals, who have interests in a nontrivial sense, but on what grounds can moral considerability be extended to plants and mountains?

One possible reply is that whatever exists is, simply by virtue of its existence, morally considerable. If this were the case, the entire burden on environmental individualism would be shifted to its criterion of moral significance: all the "claims" of morally considerable individuals (i.e., everybody) would have to be rank-orderd in a nonarbitrary way. Perhaps this could be done, but it is doubtful that this challenge really must be met. For, how can existence be a morally relevant characteristic? Leaving aside the difficulty of whether it can be a characteristic at all, one wonders why existence as such should matter. One tends to shake one's head, with John Rodman, at Zen masters who regard all things as intrinsically valuable, including smog. ${ }^{29}$ Short of adopting a theological perspective (which would yoke environmental individualism to some very questionable assumptions), it is hard to see how merely existing should entitle one to moral considerability. Moreover, reflection about future generations suggests that existence may not even be necessary for such status.

What, then, must the criterion of moral considerability be? If any beings are not to count as morally considerable, the exclusion. must be based on morally relevant characteristics. This problem must be solved if environmental individualism is to be taken seriously. Rather than do an exhaustive survey of recent attempts to solve the problem and their 
difficulties, ${ }^{30}$ I will offer a suggestion. There are certain qualities which some naturally occurring nonsentient individuals have which make them intrinsically valuable; e.g., beauty, marvelous adaption to their environments, uniqueness, their contribution to the diversity on this planet. There is a whole cluster of aesthetic qualities, one or more of which are possessed by individuals such as the Grand Canyon, a redwood tree, a stone worn smooth by a river, a bee, and a specimen of furbish lousewort. (Sentient beings may have such qualities too, but these qualities are not the primary source of their moral considerability, as discussed above.) Beings which are intrinsically valuable in any of these ways ought to be taken into account when we make a moral decision, even if they are nonsentient. Just as we ought not wantonly to deface Michelangelo's Pieta, we ought not to make picnic tables out of a 2000-year-old living redwood. Careful, informed reflection about the redwood and even about the unremarkable but rare furbish lousewort will result in our admiration and regard. Examples of beings which would not count as being morally considerable on these grounds are: a plant or nonsentient animal which, due to a disastrous mutation, has become unfit for survival, and has no other redeeming aesthetic qualities; a nonsentient being which is not in the least rare and has no other over-riding aesthetic value; most human junk, such as plastic milk jugs; and smog.

The appeal to values such as beauty, harmony, diversity, and uniqueness is hardly shockingly new: they have been on the lists of pluralistic value theorists since Plato's time. Only hedonists are apt to balk at them, and hedonism is a very dubious theory of value. What will disturb even nonhedonists, however, is the suggestion that such qualities have a place in an environmental ethic. Is it not homocentric to grant beings moral considerability on aesthetic grounds? Are we not making plants and naturally occurring objects hostage to human aesthetic preferences in the same way in which the homocentric ethic makes all nonhuman entities hostage to human interests?

This is a very serious objection, but I believe it can be handled. First, the homocentric ethic regards all nonhuman individuals, sentient or nonsentient, as instrumentally valuable only. They merely contribute to intrinsically valuable human experiences. Now, it is true that human aesthetic experiences are intrinsically worthwhile, but the suggestion that nonsentient beings which have certain aesthetic qualities be morally considerable entails that they are intrinsically valuable also. The aesthetic experiences we have are a response to these beings, not the source of their merely instrumental value. I believe reflection bears this out. Consider one's response to a strip-mined mountain. Suppose that all the sentient life which that part of the mountain had supported has been moved to an even more congenial environment. Apart from instrumental considerations (such as the economic benefits of the strip-mining), isn't one distressed at what has been done? it is not the loss of pleasurable aesthetic experiences for present and future humans that we mourn, it is the mutilation of the mountain. It is the object of our distress, not any missing experiences. Thus there is a crucial disanalogy between this view and the homocentric ethic.

But, it may now be objected, although it is true that environmental individualism does not make human beings morally prior in the way the homocentric ethic does, are we not assigning moral considerability on a "subjective," thus arbitrary, human 
basis? Whatever nonsentient beings humans happen to find aesthetically appealing make the cut, whereas others do not: they are hostage, so the objection goes, to human aesthetic preferences. A successful reply to this objection will have to draw the distinction between what merely seems to be aesthetically valuable and what is aesthetically valuable. Aesthetic judgments are no more subjective whims than are other value judgments. They must both receive the same test: they must be well-considered and as free from bias as possible. Certainly this is a very difficult undertaking but then so is the making and testing of any value judgment. This is no ground for despair, but a challenge to work in the area of environmental aesthetics. ${ }^{31}$

I conclude that environmental individualism has not been shown to stretch our concept of moral considerability out of all recognition, although some versions of it do distort the concept of rights and thus ought to be rejected.

The next objection focuses on the criterion of moral significance. It has been objected that environmental individualism, by extending the range of the morally considerable to some plants and natural objects, leads to a virtually impossible task: the necessity of resolving the many conflicting claims of humans, nonhuman animals, plants, mountains, etc. This is the objection. which inspired John Rodman's puzzled question: "My God, should we give 'America' back to the 'Indians'. . . or [to] the sumac?"32 Several other philosophers have also raised this objection. ${ }^{33}$

One thing is clear: one cannot avoid the objection by declaring that all morally considerable beings are equally valuable. Consider Albert Schweitzer's claim that
[The ethical man] does not ask how far this or that life deserves sympathy as valuable in itself, not how far it is capable of feeling. To him, life as such is sacred. ${ }^{34}$

Whom should one save: the human being or the anopheles mosquito? As Norton points out, the result of such an ethic is moral paralysis. ${ }^{35}$ Unless one were to resort to an inordinate amount of coin-tossing, inconsistency is the only answer for the moral agent who accepts this view. Schweitzer was quite admirably inconsistent: he cut down jungle to build his hospital in central Africa and labored mightily against the interests of the anopheles mosquito. ${ }^{36}$

The religion of Jainism in India has comparable difficulties. The first of five sacred vows which a Jain must make is "not to destroy life of any kind." Followers go to heroic lengths to carry out the vow: e.g., they refuse to farm because plowing and harvesting kills innocent plants and insects; they don't walk in the dark for fear of murdering unseen grass and insects; their "sky-clad" monks wear no clothes, refuse to bathe or brush their teeth (too many microbe lives would be wiped out by such actions), and wear face-masks to prevent their inadvertently swallowing insects. They are lacto-vegetarians who eat only plants which are certifiably dead (but not by murder!) and who insist on boiling (!) their milk and water. Nevertheless, consistency with the first vow is forever impossible. Even those monks who choose to starve to death rather than continue destroying life destroy their own lives. ${ }^{37}$

The primary purpose of an ethic is to serve as an action guide for the achievement of certain worthy goals. If those goals can never be achieved, the action guide is a failure. In both 
of the above reverence-for-life ethics, this is a direct consequence of the refusal to adopt a criterion for moral significance.

How then can conflicts be resolved by an environmental individualist? Donald Scherer, whose own view is primarily individualistic, suggests that "the way to deal with conflicts of positive values is three-fold: avoid them, dissolve them, or minimize them."38 This is good advice, but in whose favor do we minimize unavoidable conflicts? I think that a plausible view would have to imply that beings with interests (not in the stretched sense of 'interest' which applies to grass and lawnmowers), i.e., beings capable of having rights, should have preference over nonsentient entities, which, though they have moral standing, cannot plausibly be regarded as rights-holders. For example, the aesthetic value of a specimen of the hepatitis virus, which is marvelously well-adapted to its environment, is far outweighed by the death and suffering it and its fellows cause for sentient beings. Conflicts among rights-holders are more difficult to resolve, though this problem is hardly restricted to an environmental ethic. It is plausible to say, as Singer and Regan have argued, that we ought not to sacrifice significant interests of beings, such as life, freedom, and happiness, to the less significant interests of others, such as a liking for Kentucky-fried chicken. When there is an unavoidable clash of significant interests, all the relevant factors in the case must be taken into account and an impartial decision made. There can be no easy answers here, and one should be suspicious of a view which offers them.

The main point is this: if a very large number of beings have moral standing, then we must work out a way of resolving conflicts among them, no matter how difficult this may be.
To object to an ethic on the ground that it implies that there are a vast number of conflicts to resolve is not to the point. Following this reasoning, an ethic with the smallest possible scope of moral considerability would be the best. First-person egoism ("an act is right if and only if it maximizes my long-range expectable utility") would win the competition hands down. Thus, as this reductio argument indicates, objection (4) against environmental individualism also fails.

5. However, we now come to an objection which I do not think can be defeated. In the discussion of objection (3) above, it was argued that certain aesthetic characteristics make some nonsentient individuals morally considerable (though they are insufficient, unlike the characteristic of sentience, to make them rights-holders). But this same line of reasoning leads to the conclusion that some richly complex wholes are intrinsically valuable too. A carefully balanced ecosystem is beautiful in many respects. Even a very drab (at first glance) wilderness area, such as the 100 acres of California sage and chapparal which Rodman fought to keep from being replaced by a golf course, ${ }^{39}$ has harmony, stability, order, and variety. Whole systems of this kind, including their subsystems, have aesthetic value. They too, then, are morally considerable. The restriction of moral considerability to individuals is arbitrary. Therefore, although environmental individualism is vastly less arbitrary than the homocentric ethic, it too fails to be an adequate ethic. It must either be supplemented or replaced entirely.

\section{E. Environmental Holism}

It is tempting at this point to escape to a replacement: environmental holism. According to it, individuals have instrumental or derivative 
value only: it is the richly complex wholes which include them that are intrinsically valuable. Which richly complex wholes? The usual answer given is ecosystems. The classic statement of this view was given by Aldo Leopold, who called it "the land ethic":

A thing is right when it tends to preserve the integrity, stability, and beauty of the biotic community. It is wrong when it tends otherwise. ${ }^{40}$

One may embrace a "global" holism, according to which the "fundmental bearer of value" is the entire ecosystem on this planet, or one may accord moral considerability to smaller richly complex wholes such as wilderness areas. Whichever version of environmental holism one chooses, however, it will have the same implication for individuals: they have no value in their own right.

Let us now tke a closer look at that implication. According to environmental holism, individual members of a biotic community, however large that community might be, ought to be preserved only if they contribute favorably to that community; if they detract from the community, they ought to be eliminated if possible. The implication holds for humans as well as nonhumans. If the biotic community would benefit, abortion, infanticide, and killing of certain adults would all be justified. Measures routinely taken with nonhuman animals would be extended justifiably to humans. Now, some might think it's high time that we take our turn. It's a. short step from Garrett Hardin's proposal that we not try to rescue stranded backpackers in a wilderness area because "I have not lately heard that there is a shortage of people"41 to the recommendation that the human population be "culled". At any rate, one certainly cannot accuse this view of homocentrism!

What is the proper way for humans, as members of the biotic community, to live? According to environmental holism, they ought to interfere with natural processes as little as possible. In particular, they ought to resist subjecting the community to "mechanico-chemical" manipulation. The most eloquent spokesman for environmental holism, J. Baird Callicott, writes that:

On the ethical question of what to eat, it answers, not vegetables instead of animals, but organically as opposed to mechanico-chemically produced food. Purists like Leopold prefer, in his expression, to get their "meat from God," i.e., to hunt and consume wildlife and to gather wild plant foods, and thus to live within the parameters of the aboriginal human ecological niche. Second best is eating from one's own orchard, garden, henhouse, pig pen, and barnyard. Third best is buying or bartering organic goods. from one's neighbors and friends. ${ }^{42}$

I have two principal objections to environmental holism. Each will be considered in turn.

1. The distinction between 'natural' and 'artificial' implicit in the quote above is itself rather artificial. Human beings have evolved, through uncontroversially natural processes, into intelligent manipulators of their surroundings. Not to employ these manipulative abilities would be unnatural! Moreover, holists encourage some manipulation on our part. But it would surely be arbitrary to approve of a man's hunting with a bow and arrow while frowning on his use of a gun. (Incidentally, I have difficulty 
seeing either practice as "getting meat from God": the animals do not exactly plummet from the heavens like manna.) As regards the disapproval of the "mechanico-chemical" production: it is surely true that we have done enormous damage to animals and the nonsentient environment (not to mention ourselves) with our manufactured fertilizers, pesticides, and herbicides. But is it the "artificiality" of these products that makes them objectionable? Suppose we were able to produce cheaply and safely a fertilizer which exactly duplicates the properties of cow dung. What could possibly be wrong with substituting it for the original? If we decide that we have been wrongfully exploiting cattle for our own convenience (and holists agree with animal liberations on this point, though for different reasons), and no longer breed them as we now do, wouldn't the invention of the pseudo-cow-dung be salutary rather than an objectionable human intrusion on nature?

Similarly, suppose scientists learn to make superb vegetable-protein substitutes for chicken, beef, lamb, and veal at reasonable cost, substitutes which are indistinguishable from the originals and are not harmful to make or to eat. Untold numbers of animals would be spared factory farming, we could humanely phase out the animals we have domesticated for this purpose, and no humans would have to endure meat-taste withdrawal. Presumably, environmental holists would applaud the results of such an invention, but they would nevertheless condemn the "mechanico-chemical" nature of that invention. Surely this is misguided. The way to try to correct the damage we have done is not to abandon technology: by the holists' own reasoning, this would be an unnatural curtailment of human abilities. Instead, we ought to employ our technology much more wisely and sensitively.
It is instructive to examine holistic criticism of a very insensitive use of technology: the mass production of chicken meat and eggs. Callicott condemns such factory-farming, but not because of the misery and death it inflicts on the chicken:

From the perspective of the land ethic, the immoral aspect of the factory farm has to do far less with the suffering and killing of nonhuman animals than with the monstrous transformation of living things from an organic to a mechanical mode of being. ${ }^{43}$

It is true, as Callicott says, that we have come to treat these as mere machines. The chickens are no more than egg-assemblers and drumstick racks. Callicott sees this mechanization as yet another intrusion of humans into natural processes: this is the source of his outrage. It seems to me, however, that one's outrage stems not from the use of technology on the farm as such, but from the effects of that particular technology on sentient beings. What clearer indication could there be of our total lack of concern for the animals' interests? They have literally been turned into mere instruments for our gustatory gratification. At least the barnyard chicken is permitted some pleasant experiences before the Day of Reckoning!

Here the environmental holist will probably object that he is being attacked for being a holist, one who does not regard individuals as intrinsically valuable. In order not to beg the question against holism, I will press my argument further in the second objection below.

2. The objection is this. Environmental holism does not regard the fear, suffering, and anguish of sentient individuals, be they human or 
nonhuman, as intrinsically bad, anymore than it regards their pleasure as intrinsically good. If the biotic community requires agonizing death, so be it. It will be a human obligation to inflict such death in some cases: not only by "getting meat from God," but by culling its own ranks. The resultant suffering and death is not a "necessary evil," according to holism: only that which harms the community is evil, just as only that which benefits it is good. As Callicott points out:

Pain and pleasure seem to have nothing at all to do with good and evil if our appraisal is taken from the vantage point of ecological biology. ${ }^{44}$

I maintain that this implication is unacceptable from the moral point of view. One who clearly, impartially, and empathetically considers the agony of a human or nonhuman may, depending on the circumstances, conclude that the agony is instrumentally good, but he or she would not, I maintain, hesitate to conclude that it is intrinsically evil. ${ }^{45}$

Callicott has a reply to this sort of objection. He defends this implication of environmental holism with two arguments. First he points out that pain is necessary for survival: "A living mammal which experienced no pain would be one which had a lethal dysfunction of the nervous system." 46 Pain is also a desirable indicator that one has exerted oneself sufficiently to be fit. 47 ("No gain without pain!") Thus pain, far from being evil, is actually desirable. This argument will not do, however. All it shows is that pain can be instrumentally good for the being who experiences it. Moreover, much of the pain that human and nonhuman animals endure is not even instrumentally good for those individuals. The agony of a bird tortured for sport by a cat is in no way edifying for the bird! Callicott would probably answer this reply to his first argument with his second argument. He points out that in this world sentient beings do experience frustration, anguish, fear, agony, and death. "That is the way the system works. If nature as a whole is good, then pain and death are also good."48 But is that if-clause fulfilled? One can have intense admiration and even awe for the marvelously inter-connected complexity of life as it has evolved on this planet while at the same time wishing that some things were otherwise. It is far from obvious that a world in which animals did not have to eat each other to survive would be morally inferior to this one. Thus, neither of these arguments meets objection (2).

Moreover, other writings by Callicott suggest that he ought to agree that pain is intrinsically evil. Elsewhere he argues that the ethical basis of Leopold's view can be found in Hume's account of the moral sentiments. Love and concern for the environment as a whole is said to be an extension (not a redirection) of our natural sympathetic impulses from other members of the biotic community to the community itself:

Hume, Darwin, and Leopold all recognize in addition to social sympathies and affections for fellow members of society, whether tribal, national, or biotic, special social sentiments the object of which is society itself. Patriotism is the name of the social sentiment directed to the nation as a superorganismic entity. Presently there is no name for the emergent feeling, the object of which is the biosphere per se and its several superorganismic subsystems. We could, perhaps, call it bio-sentimentality. ${ }^{49}$ 
The fact is that those same moral sentiments lead one to regard the suffering of individuals as intrinsically evil. What the quote above suggests is that both individuals and biotic communities are morally considerable, which is contrary to the basic assumption of holism.

At this point, an environmental holist could attempt a radical reply to the objection that his view has implications about pain that are unacceptable from the moral point of view. He could choose to reject the moral point of view on the ground that it is biased in favor of individuals. It requires us to take into account the ways in which individuals would probably be affected by given actions. We are even to empathize with those individuals who are sentient. It is not surprising, he might reply, that holism would be rejected from the moral point of view! Our considered intuitions, which are based on information gained by vivid, empathetic awareness, are loaded in favor of individuals.

Callicott does not take this approach at all. He explicitly accepts the appeal to carefully considered moral intuitions. ${ }^{50}$ Would he do better to reject such an appeal and to embrace the radical reply instead? I think not. The moral point of view advocates nothing. It is the method we use to test ethical judgments. To take into account the ways in which individuals are affected or would be affected by actions is not to be biased in favor of individuals: it is merely to be informed about the situation one is judging. An environmental holist who rejected this method would be wide open to the charge that his view is uninformed. Finally, in objection (5) to environmental individualism, I argued that well-considered reflection leads to the conclusion that richly complex wholes as well as some individuals have intrinsic value. It is then not true to say that this method is necessarily opposed to holistic conceptions of value. Therefore, objection (2) to environmental holism has not been met. We have good reason to reject this conception of an environmental ethic as it stands.

\section{F. Conclusion}

I have argued that the homocentric ethic has unacceptable implications about the treatment of nonhuman animals and is an inadequate ethic for the use of the environment. Its rivals, environmental individualism and environmental holism, also have unacceptable implications, but these defects can be remedied: each fails in so far as it neglects what is right about the other. If what I have argued is correct, an adequate environmental ethic should incorporate both individualistic and holistic features. What is needed is an ethic which accords moral considerability (1) to sentient individuals, on the grounds that they have interests; (2) to those naturally occurring individuals which have aesthetically valuable characteristics; and (3) to those richly complex wholes which have aesthetically valuable characteristics. All that has been said about the criterion of moral significance in the discussion of environmental individualism above holds, but to it must be added the class of systems in (3). It will still be the case that, in cases of unavoidable conflict, rights-holders ought to have priority over beings and systems which have no interests. In cases of conflicts between naturally occurring nonsentient individuals and systems which have aesthetic value, we ought to consider (a) the consequences of proposed actions for the significant interests of rights-holders and (b) the aesthetic consequences of those proposed actions. It will be no easy matter to work out such conflicts, but, if my reasoning has been correct, work them out we must if we 
are to honor our obligations to the human and nonhuman world. ${ }^{51}$

\author{
Evelyn B. Pluhar \\ The Pennsylvania State University \\ Fayette Campus
}

NOTES

${ }^{1}$ Reported in Newsweek, July 19, 1982, pp. 26-27.

${ }^{2}$ Garrett Hardin, "The Economics of Wilderness," Natural History 78, 1969, pp. 173-77. See the citation and discussion in J. Baird Callicott's "Animal Liberation: A Triangular Affair," Environmental Ethics 2, 1980, P. 327.

${ }^{3}$ It has been pointed out to me that hedonistic utilitarians might disagree with this claim. They believe, it is alleged, that only pleasure is intrinsically valuable: beings which experience pleasure are merely instrumentally valuable because they are the vessels for such pleasure. While writers such as Peter Singer do indeed talk this way, I do not think there need be any such disagreement. A view according to which only properties, rather than the beings that have them, are intrinsically valuable, is based on a highly dubious metaphysical as sumption. The distinction between a thing and its properties is analogous to the distinction betwen a vessel and its contents only if one is committed to a substratum view. No utilitarian is obliged to make such a commitment. Beings capable of experiencing pleasure are morally considerable, according to hedonistic utilitarianism: their claims can be outweighed, but they certainly count. They are not merely instruments for the production of other value. Of course, it is their capacity for pleasure which makes them morally considerable, according to hedonistic utilitarianism, but any ethic assigns moral considerability on the basis of one or more characteristics. It does not follow from this that the characteristic, rather than its possessor, has value in its own right. Instead, it seems much more plausible to say that the characteristic is what makes the being intrinsically valuable.

${ }^{4}$ This is an adaptation of Tom Regan's two conditions for an environmental ethic. He holds that it (1) must accord moral standing to nonhumans and (2) must hold that both conscious and nonconscious beings have moral standing. (See his "On the Nature and Possibility of an Environmental Ethic," Environmental Ethics 3, 1981, pp. 19-20. My formulation does not imply that conscious (sentient) individuals have moral standing. This is the very issue between the holistic and individualistic conceptions of an environmental ethic, and it would be inappropriate to settle that issue here by stipulation.

${ }^{5}$ lbid., p. 20.

${ }^{6}$ Consider R. B. Brandt's attack on the appeal to intuitions on PP. 16-23 of his A Theory of the Good and the Right (Oxford: Oxford U. Press, 1979). His own proposal, 
that we require ethical judgments to be "fully rational," does not differ significantly from the proposal that we consult our considered intuitions. For more discussion of the problem of justification in ethics, see pp. 56-60 of my "The Justification of an Environmental Ethic," Environmental Ethics 5 (1), 1983.

${ }^{7}$ Several attempts have been made to show that speciesism is not analogous to racism and that the homocentric ethic does not base moral considerability on a morally irrelevant characteristic, but in my judgment and that of other philosophers all these attempts fail. It would require another paper to review all the literature on this subject, and rather than repeat what others have said so well, I refer the reader elsewhere. For a discussion of several such attempts see my "Must an Opponent of Animal Rights also be an Opponent of Human Rights?", Inquiry 24, 1981, pp. 229-41. See also Steve I. Sapontzis, "The Moral Significance of Interests," Environmental Ethics 4, 1982, pp. 345-358.

${ }^{8}$ Eric Katz, "Utilitarianism and Preservation," Environmental Ethics 1, 1979, pp. 362-3. The version of utilitarianism he discusses is homocentric: see pp. 357-8. See also Bryan Norton, "Environmental Ethics and Nonhuman Rights," Environmental Ethics 4, 1982, pp. 21-3.

${ }^{9}$ See Katz, p. 361; John Rodman, "The Liberation of Nature?," Inquiry 20, p. 84; and Norton, pp. $18,19,22$.

10Martin Krieger, "What's Wrong with Plastic Trees?," Science 179, 1973, p. 451, p. 453. See Mark Sagoff's discussion of this article in "On Preserving the Natural Environment," Yale Law Journal 84, 1974, p. 205. See also Katz, p. 362.
${ }^{11}$ Christopher Stone, Do Trees Have Standing? (Los Altos: William Kaufmann, 1974).

12 "The Nature and Possibility of an Environmental Ethic," pp. 19-34.

${ }^{13}$ Donald Scherer, "Anthropocentrism, Atomism, and Environmental Ethics," Environmental Ethics 4, 1982, pp. 115-123. A revised version was printed in Ethics and the Environment, D. Scherer and T. Attig, eds. (Englewood Cliffs: PrenticeHäl, 1983).

${ }^{14}$ Alistair Gunn, "Why Should We Care about Rare Species?," Environmental Ethics 2, 1980, p. 36.

${ }^{15}$ Kenneth Goodpaster, "From Egoism to Environmentalism," in Ethics and Problems of The 21st Century, Goodpaster and Sayre, eds. (Notre Dame: $U$. of Notre Dame Press, 1979), pp. 29-30.

${ }^{16}$ Callicott, p. 330.

${ }^{17}$ Ibid. John Rodman holds the same view. See his pp. 98-101.

${ }^{18}$ Callicott, p. 330.

1.9 Ibid., footnote 42. Note, however, that Callicott does not approve of factory farming. His objection is not to the misery it inflicts but rather to the mechanization we have introduced into the natural world. See my discussion of environmentalism holism below.

${ }^{2} \mathrm{I}$. n fairness to Callicott, it should be noted that the view he criticizes presupposes a Benthamite quantitatively hedonistic theory of value. If we ought only to consider quantities of pleasure and pain in making moral decisions, domestic and wild animals would be on the same footing as regards considerability and significance. 
${ }^{2}$ Goodpaster, p. 29.

22 Stone, pp. 101, $25 \mathrm{ff} ., 41 \mathrm{ff}$. Cf. Rodman, p. 84 .

${ }^{23}$ Stone, pp. 72, 105-8, 52-3.

${ }^{24}$ Ibid., p. 105.

25 Joel Feinberg, "The Rights of Animals and Unborn Generations," in William Blackstone, ed., Philosophy and Environmental Crisis (Athens, Ga.: U. of Georgia Press, 1974), p. 49.

${ }^{26}$ Norton, p. 32. See his discussion of attempts to stretch the concept of interest on pp. 30-32.

${ }^{27}$ Goodpaster, p. 29.

${ }^{28} \mathrm{~W}$. K. Frankena makes this objection in his "Ethics and the Environment," in Ethics and Problems of the 21st Century, p. 13.

29 Rodman, p. 108.

${ }^{30}$ See Frankena, pp. 10-11, and Regan, $P$. 33, for discussion of some attempts.

${ }^{31}$ One fine example of work along these lines is Lilly-Marlene Russow's "Why Do Species Matter?," Environmental Ethics 3, pp. 101-112.

${ }^{32}$ Rodman, p. 85.

${ }^{33}$ See Norton, pp. 28-33, and Goodpaster, "From Egoism to Environmentalism," p. 29.

${ }^{34}$ Albert Schweitzer, "The Ethic of Reverence for Life," ' excerpt reprinted in Animal Rights and Human Obligations, P. Singer and T. Regan, eds. (Englewood Cliffs: Prentice-Hall, 1976), p. 134.

${ }^{35}$ Norton, p. 33.
${ }^{36} \mathrm{He}$ was verbally inconsistent as well. He explicitly advocates the sacrifice of nonhuman life when "truly necessary." See his p. 137.

37 Time, March 16, 1981, "Ablution Without Absolution," and The Vegetarian Times, May 1982, pp. 21-22.

${ }^{38}$ Donald Scherer, "Anthropocentrism, Atomism, and Environmental Ethics," in Ethics and the Environment, p. 79.

${ }^{39}$ Rodman, p. 83.

${ }^{40}$ Aldo Leopold, A Sand County Almanac and Sketches Here and There (New York: Oxford U. Press, 1949), pp. 224-225. At times Leopold sounds like an individualist, such as when he suggests that the land ethic "enlarges the boundaries of the [moral] community" to include "soils, waters, plants, and animals" ( $p$. 204). However, Callicott argues that Leopold is really a holist: speaking of Leopold's definitions of 'right' and 'wrong', he observes that "What is especially noteworthy and that to which attention should be directed in this proposition, is the idea that the good of the biotic community is the ultimate measure of the moral value, the rightness or wrongness, of actions. . . in every case the effect upon ecological systems is the decisive factor in the determination of the ethical quality of actions." ("Animal Liberation: A Triangular Affair," p. 320) Although Leopold, and at times Callicott, speak in terms of the moral standing of the elements of a biotic community, they do not mean this at all in the individualist way. On their view, individuals have no moral standing in the sense of being intrinsically valuable. See Callicott, p. 324 .

${ }^{41}$ Hardin, p: 176. 
${ }^{42}$ Callicott, p. 336.

${ }^{43}$ lbid., p. 335.

44 lbid., p. 332.

${ }^{45}$ One philosopher who has expressed doubt about the judgment that pain is intrinsically evil is R. G. Frey, in Interests and Rights: The Case Against Animals (Oxford: Clarendon Press, 1980). However, his doubt appears to be the result of (1) the confusion of intrinsic with instrumental evil (see my discussion of a similar argument below) and (2) his belief that judgments of intrinsic value should be justified by an argument of some kind. Intrinsic value judgments can be justified, but not by an appeal to yet more basic value judgments. The only justification possible is metaethical: an appeal to the moral point of view.

46 lbid., p. 333.
${ }^{4} 7$ lbid., p. 332.

${ }^{48}$ Ibid., p. 333. Emphasis mine.

${ }^{49} \mathrm{P} .17$ of his "Nonanthropocentric Value Theory and Environmental Ethics," a paper read at a symposium on "Anthropocentrism and Environmental Ethics," at the March 1983 meeting of the Pacific Division of The American Philosophical Association. This paper was kindly provided to me by the author. See also his "Hume's ls/Ought Dichotomy and the Relation of Ecology to Leopold's Land Ethic," Environmental Ethics 4, pp. 163-174.

50 See "Animal Liberation," p. 335 , and "Nonanthropocentric Value Theory and Environmental Ethics," p. 5 ("[Ethical hedonism] fails to articulate our considered moral intuitions. . .")

5 I would like to thank Harlan B. Miller for his helpful comments on an earlier version of this paper. 